\title{
Dihydroergotamine (DHE) - Is there a place for its use?
}

\author{
Agnieszka Piechal', Kamilla Blecharz-Klin'1, Dagmara Mirowska-Guzel' \\ ${ }^{1}$ Medical University of Warsaw, Poland
}

Piechal A, Blecharz-Klin K, Mirowska-Guzel D. Dihydroergotamine (DHE) - Is there a place for its use? J Pre-Clin Clin Res. 2018 ; 12(4): 149-157. doi: $10.26444 / j p c c r / 99878$

\begin{abstract}
Nowadays, dihydroergotamine (DHE) is sporadically used as a vasoconstrictor in the treatment of acute migraine. The importance of this drug in medicine has significantly decreased in the recent years. Limitations on the use of dihydroergotamine are due to the high toxicity and increased the risk of severe adverse events after prolonged theraphy. The Committee for Medicinal Products for Human Use of the European Medicines Agency recommends limiting the use of drugs that contain ergotamine derivatives due to the potential risk of ischemic vascular events, fibrosis and ergotism. However, ergot alcaloids preparations are not recommended for use in the prophylaxis of migraine pain, although it is still a good alternative for people with status migrainosus, migraine recurrence or chronic daily headache that do not respond to the classical theraphy. In clinical practice, DHE can be used as a rescue medication to treat migraine attacks involving aura or without aura, as well as for the acute treatment of cluster headache episodes. The effectiveness of DHE in alleviating migraine headache was assessed in multiple clinical studies. This review describes the pharmacodynamic and pharmacokinetic properties of DHE in an expanded view and its role in modern therapy based on available clinical trials. Most clinical data confirm that the drug is still an important element of contemporary migraine therapy, especially in cases when conventional medicine fails.
\end{abstract}

\section{Key words}

dihydroergotamine, migraine, efficacy, safety

\section{INTRODUCTION}

Migraine is estimated to affect $18 \%$ of women and $6 \%$ of men, causing their quality of life to deteriorate and generating considerable costs for the healthcare system. Vasodilation of the extracranial blood vessels is considered to play a key role in the pathophysiology of migraine headaches. For some people with migraine who do not respond to the classical analgesics, therapy with dihydroergotamine (DHE) is a good alternative, particularly for people with status migrainosus, migraine recurrence, chronic daily headache, or those who suffer from medication-overuse headache (MOH). DHE can be used to treat migraine attacks involving aura or without aura, as well as for the acute treatment of cluster headache episodes $[1,2,3]$.

Dihydroegrgotamine (DHE) pharmocodynamics. DHE is occasionally used as a rescue medication for acute migraine headache and as first-line therapy in the treatment of drugresistant migraine headaches. The therapeutic effect of DHE comprises vasoconstriction of the carotid artery beds via modulation of the serotonergic system. This mechanism is based mostly on the drug bonding with $5-\mathrm{HT}_{1 \mathrm{Da}}$ and 5- $\mathrm{HT}_{1 \mathrm{D}}$ serotonin receptors, as well as with $5-\mathrm{HT}_{1 \mathrm{~A}}, 5-\mathrm{HT}_{2 \mathrm{~A}}, 5-\mathrm{HT}_{1 \mathrm{~B}}$, $5-\mathrm{HT}_{2 \mathrm{C}}, 5-\mathrm{HT}_{1 \mathrm{E}}, 5-\mathrm{HT}_{1 \mathrm{~F}}$, and $5-\mathrm{HT}_{4}$ serotonin receptors $[4,5$, $6,7,8]$. As an agonist, DHE stimulates serotonin receptors located in the intracranial blood vessels, including those on arterio-venous anastomoses, leading to vasoconstriction. Simultaneously, activation of these receptors on sensory nerve endings of the trigeminal system inhibits the release of pro-inflammatory neuropeptides, such as calcitonin gene-related peptide (CGRP), which plays a key role in the

Adress for correspondence: Kamilla Blecharz-Klin, Medical University of Warsaw, Banacha 1B, 02-097 Warsaw, Poland

E-mail: kamilla.blecharz-klin@wum.edu.pl

Received: 11 October 2018; Acceptewd: 20 November 2018 development of migraine pain. Furthermore, the drug has a strong affinity for other types of receptors, e.g. adrenergic $\left(\alpha_{1 \mathrm{~A}}, \alpha_{1 \mathrm{~B}}, \alpha_{2 \mathrm{~A}}, \alpha_{2 \mathrm{~B}}, \alpha_{2 \mathrm{C}}\right)$ and dopaminergic $\left(\mathrm{D}_{2 \mathrm{~L}}, \mathrm{D}_{3}, \mathrm{D}_{4}\right)$.

Studies indicate that DHE also limits ATP-mediated sensitization of trigeminal ganglion neurons and inhibits the expression of $\mathrm{P} 2 \mathrm{X} 3$ membrane receptor, which is important for peripheral pain responses and plays a significant role in migraine pathology [9]. Additionally, DHE decreases activation of the trigeminal nucleus caudalis by inhibiting the release of prostaglandins from glia $[10,11]$.

In the past, DHE was also recommended for treating dementia, including Alzheimer's disease, because it inhibits binding of amyloid- $\beta$ oligomers on ephrin type-B receptor 2 , but this type of treatment is currently less practiced [12].

Pharmacokinetics of DHE. The pharmacokinetic parameters characteristic of DHE can vary depending on the route of administration (Tab. 1). According to Silberstein and Kori [13], who presented an overview of the pharmacokinetic properties of various DHE formulations, the peak concentration occurs 6 minutes after intravenous administration, 34 minutes after intramuscular administration, 56 minutes after intranasal administration, and 12 minutes after oral inhalation, whereas after oral administration it occurs after 75 minutes. Due to the high first-pass effect, the bioavailability of the drug after oral administration is low ( $1 \%$, total bioavailability of DHE and its active metabolites does not exceed 6-8\%); thus, the preferred routes of administration are intravenous and intramuscular (bioavailability close to 100\%). DHE can also be used subcutaneously, intramuscular, intranasally or via oral inhalation $[14,15,16,17,18]$. Oral inhalation of DHE (MAP0004) allows therapeutic concentrations to be achieved in a short time ( 10 minutes) and causes fewer adverse effects than intravenous administration due to the selective influence of the drug, when thus administered, on $5-\mathrm{HT}_{1 \mathrm{~B}}$ and $5-\mathrm{HT}_{\mathrm{D}}$ receptors $[19,20]$. DHE intended for intranasal 
administration is also well tolerated by patients, and such drug administration is convenient and non-invasive.

The drug binds well to serum proteins (93\%) and the volume of distribution in adult patients is $800 \mathrm{~L}$ [21]. The most important enzyme for hepatic metabolism of DHE is CYP3A4. The main DHE metabolite is 8 'hydroxydihydroergotamine (8'OH-DHE), which also has vasodilatory properties. Other active metabolites include 8',10'-dihydroxydihydroergotamine (8'10'OH-DHE) and dihydrolysergic acid amide (DH-LSA) [4, 22].

DHE is eliminated by the liver in the bile and excreted in faeces (clearance $1.5 \mathrm{~L} / \mathrm{min}$ ). Only $6-7 \%$ of DHE is excreted unchanged in the urine. The $\mathrm{T}_{1 / 2}$ for the drug is $10-13 \mathrm{~h} \mathrm{[23]}$. In addition, the drug slowly dissociates from bonds with the receptor which causes a longer pharmacological effect than the concentration of the drug in blood plasma would suggest. The prolonged effect on blood vessels is also related to active metabolites, which have vasodilatory properties similar to the original compound.

\section{DIHYDROERGOTAMINE IN THE TREATMENRT OF}

MIGRAINE. The use of DHE is sometimes recommended for the treatment of acute migraine pain in the case of resistance to other drugs. Studies have shown that DHE is effective in the case of menstrual migraines, migraines with cutaneous allodynia, migraine recurrence, status migrainosus, and headaches caused by using other drugs. DHE should be given to patients in emergency situations, preferably for a short period of time. Currently, DHE preparations are not recommended for use in the prophylaxis of migraine pain, as prolonged use of the drug significantly increases the risk of severe adverse events. The current recommended route of DHE administration is intravenous, whereas subcutaneous, intramuscular, and intranasal administration are less often chosen (Tab. 2-5). Oral administration of the drug is not currently advisable.

The effectiveness of DHE in alleviating migraine headache was assessed in multiple clinical studies, but only some of them concerned classical, oral administration of the drug (Tab. 3). Studies indicate that, regarding such administration, the therapeutic effect is negligible. In a double-blind, placebocontrolled PROMISE study, which lasted for 5 months and included 363 patients suffering from migraines, no significant advantage was noted with the use of modified-release DHE capsules over placebo in the prevention of migraine headaches [24]. Hämäläinen et al. [25] made observations regarding children with migraine and concurred that the effect of using DHE per os (20 or $40 \mu \mathrm{g} / \mathrm{kg}$ ) is comparable to using placebo.

Currently, due to low bioavailability, oral administration of DHE is not justifiable, but intravenous administration can have a potentially good effect [26]. The potential advantages of intravenous administration of DHE to patients with migraine headaches have been subject to multiple analyses and clinical studies (Tab. 2). Studies suggest that both continuous infusions and multiple DHE injections are equally effective and have a similar safety profile for persons with migraine [27]. Intravenous administration of DHE also alleviates episodic cluster headache and is effective in the case of recurrent headaches [28, 29, 30]. Becker et al. [31] described the efficacy of DHE administered intravenously to patients in a home environment over the course of 21 weeks of observations. Among the 51 patients participating in the study, 35\% had a very good response and $18 \%$ a good response to the treatment. However, $35 \%$ of the patients stopped using DHE due to cumbersome adverse effects [31].

One possibility for migraine therapy is using orally inhaled DHE, which is better tolerated by the patients. Good efficacy was noted regarding both acute migraine symptoms (e.g., pain, phonophobia, and photophobia) and allodynia (Tab. 3). However, there is no scientific basis on which to claim that orally inhaled DHE demonstrates the same efficacy as intravenously administered DHE. Studies show that $\mathrm{C}_{\max }$ is much lower with oral inhalation than with intravenous administration. At the same time, the vasodilatory effect is diminished and binding of 5- $\mathrm{HT}_{2 \mathrm{~B}}$ receptors limited, which minimizes fibrotic complications. Other adverse effects, such as nausea, also occur less often. Yet, there are no discernible effects on asthma and pulmonary arterial systemic pressure. Taking into account all of these factors, one can maintain that this route of administration is useful in specific situations, such as morning migraine, migraine with quick time to onset, prolonged migraine, status migrainous, and menstrually related migraine [32].

According to FDA recommendations, a contraindication for triptans and DHE is basilar and haemiplegic migraine due to the potential risk of ischemic vascular events. For this reason, patients with this type of migraine were not included in the clinical studies designed to assess the efficacy of intravenously administered DHE. However, in 2016, the results of a study evaluating the efficacy and safety of abortive treatment was published concerning this group of patients [33]. The study included 67 patients with basilar migraine and 13 patients with haemiplegic migraine. The risk of occurrence of severe adverse effects, such as stroke and myocardial infarction, did not increase with the use of DHE. However, this study included only a small group of patients.

The effectiveness of classical migraine therapy in children requires a separate analysis. This group of patients in general reacts differently to commonly used anti-migraine therapy. A meta-analysis published in 2013 showed that paediatric patients' reactions to conventional treatment are weaker. With regard to children, migraine prophylaxis with classical drugs, such as trazodone and topiramate, is rather ineffective, whereas the effectiveness of other antimigraine medications (e.g., clonidine, flunarizine, pizotifen, propranolol, valproate) is comparable to placebo [34]. In a retrospective overview of 31 randomized controlled clinical studies, the most effective and safest medications for the acute treatment of migraine and headaches of different origin in the paediatric population were ibuprofen, prochlorperazine, and triptans. Similar conclusions can be drawn from a meta-analysis of 139 clinical studies concerning acute treatment of paediatric migraine that also included studies involving DHE. The studies demonstrated that only ibuprofen and sumatriptan showed efficacy higher than placebo [35].

Other results were obtained by Kabbouche et al. [29]. On the basis of a retrospective study involving the analysis of data from the hospital information sheets of 32 young patients (average age $14.52 \pm 1.91$ years), he showed that the efficacy of $\mathrm{DHE}(0.5$ or $1 \mathrm{mg}$, intravenous) is quite high when it comes to status migrainosus in the pediatric population.

Similarly, a retrospective overview of hospital treatment in a group of children in 2001-2010 showed that, despite high effectiveness in stopping migraine attacks, intravenously administered DHE provides only short-term improvement 
Table 1. Pharmacokinetics of DHE (1mg) $)^{13,17}$

\begin{tabular}{|c|c|c|c|c|c|}
\hline Drug administration & Bioavailability (\%) & Mean AUC & Mean $\mathrm{T}_{\max }(\min )$ & Mean $C_{\max }(p g / m L)$ & $\mathrm{T}_{1 / 2}(\mathrm{~h})$ \\
\hline $\begin{array}{l}\text { Intravenous } \\
\quad(n=16)\end{array}$ & 100 & $\begin{array}{c}610 \\
\text { AUC (0-infinity, pg h/mL) }\end{array}$ & 6 & 45.29 & 11.8 \\
\hline Intranasal $(n=18)$ & 40 & $\begin{array}{c}5.3 \\
\text { AUC (0-infinity, ng h/mL) }\end{array}$ & 56 & 1.02 & 8 \\
\hline $\begin{array}{l}\text { Oral } \\
(n=9)\end{array}$ & 1 & $\begin{array}{c}98 \\
\text { AUC }(0-8 \text { h, ngmin/mL) }\end{array}$ & 75 & 400 & NR \\
\hline
\end{tabular}

AUC - Area Under the Curve; $T_{\max }$ - time to reach maximum plasma concentration; $C_{\max }$ - maximum plasma drug concentration; $N R$ - not reported

Table 2. Summary of clinical data on therapeutic efficacy of intravenous dihydroergotamine in the treatment of headaches

\begin{tabular}{|c|c|c|c|c|c|}
\hline $\begin{array}{l}\text { Author/ } \\
\text { date of publication }\end{array}$ & Study & & Dosage & Patients & Results \\
\hline Bell et al. 1990 [54] & $\begin{array}{l}\text { Randomized and } \\
\text { single-blinded } \\
\text { study }\end{array}$ & & $\begin{array}{l}\text { DHE }(1 \mathrm{mg}) \text { or chlorpromazine } \\
(12.5-37.5 \mathrm{mg}) \text { or lidocaine } \\
50 \mathrm{mg} \text { i.v. }\end{array}$ & $\begin{array}{l}76 \text { patients with acute } \\
\text { migraine }\end{array}$ & $\begin{array}{l}\text { Reduction of headache intensity significantly better } \\
\text { after chlorpromazine } \\
\text { Persistent headache relief experienced by } \\
88.9 \% \text { chlorpromazine-treated patients, } 52.6 \% \\
\text { dihydroergotamine-treated patients and } 29.4 \% \text { of } \\
\text { the lidocaine-treated group }\end{array}$ \\
\hline Ford et al. 1997 [27] & Retrospective study & & $\begin{array}{l}\text { DHE } 45 \text { in constant-rate } \\
\text { intravenous infusion or multiple } \\
\text { i.v. administration }\end{array}$ & $\begin{array}{l}171 \text { patients with recurrent } \\
\text { headaches }\end{array}$ & $\begin{array}{l}\text { Constant-rate infusion is as effective and safe as } \\
\text { repeating i.v. injections }\end{array}$ \\
\hline $\begin{array}{l}\text { Magnoux and Zlotnik } \\
2004[28]\end{array}$ & $\begin{array}{l}\text { Data from hospital } \\
\text { patient information } \\
\text { sheets }\end{array}$ & & DHE i.v. & $\begin{array}{l}97 \text { patients with episodic } \\
\text { or chronic cluster } \\
\text { headache }\end{array}$ & $\begin{array}{l}\text { Good effect in particular with regard to the episodic } \\
\text { form }\end{array}$ \\
\hline $\begin{array}{l}\text { Kabbouche et al. } \\
\text { 2009 [29] }\end{array}$ & $\begin{array}{l}\text { Data from hospital } \\
\text { patient information } \\
\text { sheets }\end{array}$ & & DHE (0.5 or $1 \mathrm{mg})$ i.v. & $\begin{array}{l}32 \text { children or youngsters } \\
\text { aged } 14.52 \pm 1.91 \text { years old }\end{array}$ & $\begin{array}{l}\text { High efficacy regarding status migrainosus in } \\
\text { pediatric population }\end{array}$ \\
\hline $\begin{array}{l}\text { Charles and von } \\
\text { Dohln } 2010 \text { [30] }\end{array}$ & $\begin{array}{l}\text { Outpatient home- } \\
\text { based study }\end{array}$ & & $\begin{array}{l}\text { DHE administered via constant- } \\
\text { rate intravenous infusion } \\
3 \mathrm{mg} 42 \mathrm{ml} / \mathrm{h} \text { (day } 1-2 \text { ) and } \\
1.5 \mathrm{mg} 21 \mathrm{ml} / \mathrm{h} \text { (day } 3 \text { ) }\end{array}$ & $\begin{array}{l}31 \text { patients with chronic } \\
\text { headache }\end{array}$ & $\begin{array}{c}\text { Pain relief by over } 60 \% \text {, decrease of headache } \\
\text { attacks frequency in } 86 \% \text { of the patients; well- } \\
\text { tolerated }\end{array}$ \\
\hline $\begin{array}{l}\text { Whyte et al. } 2010 \\
\qquad[36]\end{array}$ & Retrospective study & $\stackrel{\text { : }}{:}$ & DHE i.v. & $\begin{array}{l}\text { patients with basilar-type } \\
\text { migraine }\end{array}$ & $\begin{array}{l}\text { DHE showed no serious adverse events in patients } \\
\text { with } 1 \text { posterior fossa symptom and migraine }\end{array}$ \\
\hline Nagy et al. 2011 [56] & Cohort study & & DHE i.v. & $\begin{array}{l}163 \text { patients with } \\
\text { refractory primary } \\
\text { headaches }\end{array}$ & $\begin{array}{l}\text { DHE is well-tolerated, and longer treatments } \\
\text { ( }>5 \text { days) produce a better outcome. Nausea is the } \\
\text { most common adverse effect }\end{array}$ \\
\hline Raina et al. 2013 [57] & Pilot study & & $\begin{array}{l}\text { DHE i.v. started at } 0.5 \mathrm{mg} \text { dose } \\
\text { and on average } 7 \text { to } 9 \mathrm{mg}\end{array}$ & $\begin{array}{l}6 \text { children (13-19 years } \\
\text { old) with intractable } \\
\text { abdominal migraine who } \\
\text { do not respond to classical } \\
\text { treatment }\end{array}$ & $\begin{array}{c}\text { DHE is a treatment option in children with } \\
\text { intractable abdominal migraine. } 5 / 6 \text { patients } \\
\text { responded to the DHE without significant side } \\
\text { effects. }\end{array}$ \\
\hline $\begin{array}{l}\text { Lambru et al. } 2015 \\
\qquad[58]\end{array}$ & Observational study & & DHE i.v. & $\begin{array}{l}24 \text { patients with SUNCT } \\
\text { and SUNA symptoms }\end{array}$ & $\begin{array}{c}\text { DHE is an ineffective treatment option for SUNCT } \\
\text { and SUNA, } 5 \text { patients reported dramatic worsening } \\
\text { of the SUNCT/SUNA, DHE can lead to a de novo } \\
\text { onset of SUNCT/SUNA }\end{array}$ \\
\hline Eller et al. 2016 [59] & Retrospective study & & $\begin{array}{l}\text { DHE }(0.5,0.75,1 \mathrm{mg}) \text { i.v. } \\
\text { after prior medication with } \\
\text { antiemetic drugs or aspirin }\end{array}$ & $\begin{array}{l}274 \text { patients with chronic } \\
\text { migraine }\end{array}$ & $\begin{array}{l}78 \% \text { of patients experienced medium-term } \\
\text { headache improvement. An important factor } \\
\text { responsible for the treatment effectiveness as } \\
\text { considered to be nausea relief }\end{array}$ \\
\hline $\begin{array}{c}\text { Mathew et al. } 2016 \\
\text { [33] }\end{array}$ & $\begin{array}{l}\text { Retrospective, } \\
\text { multicentre study }\end{array}$ & & DHE or triptans i.v. & $\begin{array}{l}67 \text { patients with basilar } \\
\text { and haemiplegic migraine }\end{array}$ & No serious adverse effects \\
\hline $\begin{array}{l}\text { Nelson et al. } 2017 \\
{[60]}\end{array}$ & $\begin{array}{l}\text { Retrospective } \\
\text { overview } \\
\text { of pediatric } \\
\text { hospitalizations }\end{array}$ & & DHE i.v. & $\begin{array}{l}145 \text { children (mean age } \\
\text { 14.9) out which } 74 \% \text { were } \\
\text { female }\end{array}$ & Temporary improvement, large cost of treatment \\
\hline
\end{tabular}

SUNCT - short-lasting unilateral neuralgiform headache attacks with conjunctival injection and tearing; SUNA - short-lasting unilateral neuralgiform headache attacks with cranial autonomic symptoms 
Tabble 3. Summary of clinical data on therapeutic efficacy of dihydroergotamine in the treatment of headaches (oral route)

\begin{tabular}{|c|c|c|c|c|c|}
\hline $\begin{array}{c}\text { Author/ } \\
\text { date of publication }\end{array}$ & Study & & Dosage & Patients & Results \\
\hline $\begin{array}{c}\text { Aurora et al. } 2009 \\
{[61]}\end{array}$ & $\begin{array}{l}\text { Randomised, double-blind, } \\
\text { placebo-controlled study }\end{array}$ & \multirow{3}{*}{ 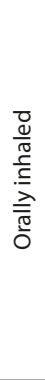 } & DHE (MAP0004) 0.5 or $1 \mathrm{mg}$ & $\begin{array}{l}86 \text { aged } 18-60 \text {-year-old } \\
\text { patients with acute } \\
\text { migraine }\end{array}$ & $\begin{array}{l}\text { Pain relief } 2 \text { hours after administration; the drug } \\
\text { was well-tolerated }\end{array}$ \\
\hline $\begin{array}{l}\text { Aurora et al. } 2011 \\
{[62]}\end{array}$ & $\begin{array}{l}\text { Randomised, double-blind, } \\
\text { placebo-controlled study }\end{array}$ & & $\begin{array}{l}\text { Rescue medication, DHE } \\
\text { (MAP0004) } 1 \mathrm{mg} \text { DHE or placebo }\end{array}$ & $\begin{array}{l}903 \text { men aged } 18-65 \\
\text { patients with episodic } \\
\text { migraine }\end{array}$ & $\begin{array}{l}\text { Pain relief, freedom from phonophobia, } \\
\text { photophobia, nausea and vomiting } 2 \text { hours after } \\
\text { administration of the drug }\end{array}$ \\
\hline $\begin{array}{c}\text { Tepper et al. } 2012 \\
{[63]}\end{array}$ & $\begin{array}{l}\text { Post hoc subanalysis of } \\
\text { randomized, double-blind, } \\
\text { placebo-controlled, } 2 \text { arm, } \\
\text { phase } 3 \text { multicentre study }\end{array}$ & & DHE (MAP0004) or placebo & $\begin{array}{l}902 \text { patients with } \\
\text { migraine with or } \\
\text { without allodynia }\end{array}$ & $\begin{array}{l}\text { Good efficacy of the drug in treating migraine } \\
\text { with and without allodynia, good efficacy in relief } \\
\text { of acute migraine symptoms, e.g. pain, phono- } \\
\text { and photophobia, nausea. The drug also prevents } \\
\text { the occurrence of allodynia in patients }\end{array}$ \\
\hline $\begin{array}{l}\text { Hämäläinen et al. } \\
1997 \text { [25] }\end{array}$ & $\begin{array}{l}\text { Controlled, double-blind, } \\
\text { placebo-controlled, pilot } \\
\text { study }\end{array}$ & \multirow{2}{*}{$\begin{array}{l}\tilde{0} \\
\stackrel{ \pm}{\square}\end{array}$} & DHE $(20$ or $40 \mu \mathrm{g} / \mathrm{kg})$ p.o. & $\begin{array}{l}12 \text { children with } \\
\text { migraine symptoms } \\
\text { who did not react to } \\
\text { conventional analgesics }\end{array}$ & Slightly better pain relief effect than placebo \\
\hline $\begin{array}{l}\text { Pradalier et al. } \\
\text { 2004 [24] }\end{array}$ & $\begin{array}{l}\text { Controlled, double-blind, } \\
\text { placebo-controlled, } \\
\text { parallel-group study }\end{array}$ & & $\begin{array}{l}\text { Seglor capsules, a unique } \\
\text { modified-release formulation of } \\
\text { dihydroergotamine mesilate } \\
\text { p.o. or placebo for } 5 \text { months after } \\
\text { a 1-month placebo run-in phase }\end{array}$ & 363 migraine patients & $\begin{array}{l}\text { Effectiveness of DHE in patients with migraine- } \\
\text { related quality-of-life impairment, effect } \\
\text { comparable to placebo }\end{array}$ \\
\hline
\end{tabular}

Table 4. Summary of clinical data on therapeutic efficacy of dihydroergotamine in the treatment of headaches (s.c or i.m. route)

\begin{tabular}{ccccc}
\hline $\begin{array}{c}\text { Author/ } \\
\text { date of publication }\end{array}$ & Study & Dosage & Patients & Results \\
\hline $\begin{array}{c}\text { Becker et al. } 1996 \\
{[2]}\end{array}$ & $\begin{array}{c}\text { Clinical data and } \\
\text { telephone interview }\end{array}$ & $\begin{array}{c}\text { DHE s.c. (1mg or less if } \\
\text { there are adverse effects) }\end{array}$ & $\begin{array}{c}51 \text { patients with } \\
\text { headache }\end{array}$ & $\begin{array}{c}\text { Very good (35\%) or good response to treatment (18\%). } \\
\text { However, 35\% of the patients stopped using DHE due to } \\
\text { cumbersome adverse effects. }\end{array}$ \\
& & 21 weeks & &
\end{tabular}

$\dot{\leftrightarrow}$

\begin{tabular}{cc}
\hline $\begin{array}{c}\text { Winner et al. } 1996 \\
\text { [64] }\end{array}$ & $\begin{array}{c}\text { Double-blind, } \\
\text { randomized trial with } \\
\text { parallel treatment } \\
\text { arms }\end{array}$
\end{tabular}

\begin{tabular}{ccc}
\hline DHE (1 mg) or sumatriptan & $\begin{array}{c}295 \text { patients total with } \\
(6 \mathrm{mg}) \text { s.c. }\end{array}$ & DHE poorer headache relief in 2 hours compared to \\
headache & sumatriptan; no difference after 4 hours
\end{tabular}

\begin{tabular}{ccccc}
\hline $\begin{array}{c}\text { Saadah } \\
1992[65]\end{array}$ & Observational study & $\begin{array}{c}\text { DHE (1 } 1 \mathrm{mg}) \text { i.m. after prior } \\
\text { ineffective p.o. treatment }\end{array}$ & $\begin{array}{c}43 \text { patients with } \\
\text { headache after oral } \\
\text { medications failed to } \\
\text { abort their headaches }\end{array}$ & $\begin{array}{c}\text { Headaches were successfully aborted in 71\%; side-effects in } \\
\text { headaches. i.m. administration is cost effective, can reduce the } \\
\text { need for narcotic analgesics and emergency room visits }\end{array}$ \\
\hline $\begin{array}{c}\text { Silberstein et al. } \\
2007 \text { [66] }\end{array}$ & Open-label pilot & $\begin{array}{c}9 \text { patients with } \\
\text { occasions) }\end{array}$ & $\begin{array}{c}\text { Improvement in terms of headache relief and cutaneous } \\
\text { allodynia } \\
\text { cutaneous allodynia }\end{array}$ \\
\hline
\end{tabular}

in this group of patients. At the same time, hospitalization costs were high in this group of patients, and long-term results in patients with chronic migraine or patients suffering from chronic headaches have been moderately successful [36]. Furthermore, a meta-analysis that took into account 8 randomized controlled trials showed that the main advantage of therapy involving DHE compared to triptans is a relatively slow and long-lasting antimigraine effect [37].

Combined therapy for migraine. During intravenous administration of DHE, the most frequent adverse effect is nausea which affected $33-67 \%$ of patients; therefore, antiemetic medication is recommended to be used with DHE. The administration of DHE together with antiemetic medication has good results in both adult patients and the paediatric population (Tab. 6), and are recommended for selected patients with refractory migraine as the second or third-line therapy [38]. Colman et al. [39] performed a meta-analysis and evaluated 11 randomized controlled trials in which adults with migraine headaches were administered $1 \mathrm{mg}$ of DHE intravenously, intramuscularly, or subcutaneously. Giving DHE together with an antiemetic drug allows for better pain management and decreases nausea.

Data prepared by Kelley and Tepper [11] suggest that the best combination is administering DHE with metoclopramide to patients with patients DHE. DHE used individually at a dose of $1 \mathrm{mg}$ (intravenous or subcutaneous) is not as effective as prochlorperazine (intravenous), but at the same time, DHE can enhance the analgesic effect of prochlorperazine. According to the presented data, DHE takes longer to provide pain relief than sumatriptan when administered subcutaneously, but the improvement is longer lasting. Studies also show that combining DHE with triptans is beneficial and can reduce the cost of therapy.

Restrictions on the medical use of DHE. Preparations with DHE should be used with caution in patients who are hypersensitive to ergot alkaloids or have renal or liver insufficiency, ischemic heart disease, cardiac arrhythmias, 
Table 5. Summary of clinical data on therapeutic efficacy of dihydroergotamine in the treatment of headaches (nasal spray)

\begin{tabular}{|c|c|c|c|c|c|}
\hline $\begin{array}{l}\text { Author/ } \\
\text { date of publication }\end{array}$ & Study & & Dosage & Patients & Results \\
\hline $\begin{array}{c}\text { Andersson \& } \\
\text { Jespersen } 1986[67]\end{array}$ & $\begin{array}{l}\text { Double-blind, randomised, } \\
\text { controlled study }\end{array}$ & \multirow{5}{*}{ 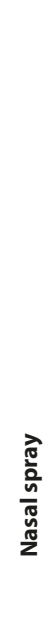 } & DHE nasal spray (1mg) & $\begin{array}{l}25 \text { patients with } \\
\text { cluster headache }\end{array}$ & $\begin{array}{l}\text { No effect on the attack frequency or the duration of the single } \\
\text { attack, significant effect on the intensity of the single attacks }\end{array}$ \\
\hline $\begin{array}{l}\text { Tulunay et al. } 1987 \\
\text { [68] }\end{array}$ & $\begin{array}{l}\text { Double-blind crossover } \\
\text { study with placebo }\end{array}$ & & $\begin{array}{l}\text { DHE nasal spray (total } \\
\text { mean of } 1.36 \mathrm{mg} / \text { attack) }\end{array}$ & $\begin{array}{l}17 \text { patients with } \\
\text { migraine }\end{array}$ & $\begin{array}{l}\text { DHE is not an effective } \\
\text { treatment for the acute migraine attack }\end{array}$ \\
\hline $\begin{array}{l}\text { Jenzer \& } \\
\text { Bremgartner } 1990 \\
\text { [69] }\end{array}$ & Open multicentre study & & DHE nasal spray & $\begin{array}{l}904 \text { patients with } \\
\text { common and } \\
\text { classical migraine }\end{array}$ & $\begin{array}{c}\text { Good efficacy in } 76.8 \% \text { of all the patients when used already } \\
\text { in the prodromal phase, good efficacy in } 63 \% \text { of patients, } 3.9 \% \\
\text { of the patients stopped using the medication due to adverse } \\
\text { effects }\end{array}$ \\
\hline $\begin{array}{l}\text { Ziegler et al. } 1994 \\
\text { [70] }\end{array}$ & $\begin{array}{l}\text { Multicentre, double-blind, } \\
\text { parallel-group study }\end{array}$ & & DHE nasal spray (2mg) & $\begin{array}{l}112 \text { patients with } \\
\text { migraine }\end{array}$ & $\begin{array}{l}\text { DHE nasal spray is a safe and effective treatment for the pain } \\
\text { and nausea of migraine attacks }\end{array}$ \\
\hline $\begin{array}{l}\text { Touchon et al. } 1996 \\
\text { [71] }\end{array}$ & $\begin{array}{l}\text { Multicentre, double-blind, } \\
\text { double-dummy, cross-over } \\
\text { study }\end{array}$ & & $\begin{array}{l}\text { DHE nasal spray }(1-2 \mathrm{mg}) \\
\text { or sumatriptan }(6 \mathrm{mg}) \text { s.c. }\end{array}$ & $\begin{array}{l}266 \text { adult } \\
\text { migraineurs }\end{array}$ & $\begin{array}{c}\text { Sumatriptan has a faster onset of action than DHE and } \\
\text { provides greater relief of acute migraine symptoms, both } \\
\text { treatments were well tolerated }\end{array}$ \\
\hline $\begin{array}{l}\text { Boureau et al. } 2000 \\
\text { [73] }\end{array}$ & $\begin{array}{l}\text { Controlled, randomised } \\
\text { study }\end{array}$ & & $\begin{array}{l}\text { DHE nasal spray }(1 \mathrm{mg} \\
\text { plus optional } 1 \mathrm{mg}) \text { or } \\
\text { sumatriptan }(20 \mathrm{mg}) \text { also } \\
\text { nasal spray }\end{array}$ & $\begin{array}{l}368 \text { patients with } \\
\text { acute migreine }\end{array}$ & $\begin{array}{l}\text { Sumatriptan is superior to DHE nasal spray in the relief of } \\
\text { pain and nausea associated with acute migraine headache }\end{array}$ \\
\hline $\begin{array}{l}\text { Weintraub } 2006 \\
\quad[74]\end{array}$ & $\begin{array}{l}\text { Prospective open trial } \\
\text { Pilot study }\end{array}$ & & $\begin{array}{l}\text { DHE nasal spray }(2 \mathrm{mg}) \text { as } \\
\text { prophylaxis every } 8 \mathrm{~h} \text { for } \\
3 \text { days }\end{array}$ & $\begin{array}{l}24 \text { patients } \\
\text { refractory } \\
\text { headache }\end{array}$ & Effective and safe in the treatment of refractory headache \\
\hline $\begin{array}{l}\text { Fisher et al. } 2007 \\
\qquad \text { [75] }\end{array}$ & Retrospective study & & DHE nasal spray (2mg) & $\begin{array}{l}97 \text { patients who } \\
\text { do not respond } \\
\text { to treatment with } \\
\text { triptans }\end{array}$ & $\begin{array}{l}\text { In } 34 \% \text { of the patients the symptoms were relieved, and in } \\
39.2 \% \text { there was no response to the treatment (pain measured } \\
\text { according to VAS scale). In } 7.2 \% \text { of the patients there were } \\
\text { adverse drug reactions (nose irritation, dysphoria) }\end{array}$ \\
\hline
\end{tabular}

uncontrolled arterial hypertension, thrombotic peripheral vascular diseases, or sepsis [23].

The Committee for Medicinal Products for Human Use (CHMP) of the European Medicines Agency recommends introducing restrictions on the use of drugs that contain ergotamine derivatives due to the risk of fibrosis and ergotism. Drugs from this group should not be used for the treatment of cognitive disorders, sensory disorders, cardiovascular disorders, or prevention of migraine headaches, because the risk of adverse events (e.g., ergotamine poisoning, organ fibrosis) outweighs the potential benefits [40].

DHE is classified under the X pregnancy category and cannot be used during pregnancy or breastfeeding. The drug causes uterine contractions in pregnant women and neonatal asphyxia. It also inhibits prolactin secretion, a hormone produced mainly by the anterior pituitary lobe cells, as well as by extrapituitary sources, such as the ovaries, endometrium, breast glands, and peripheral blood lymphocytes. According to some authors, DHE can increase the risk of congenital anomalies and spontaneous abortions and cause low birth weight [41]. Pre-clinical trials confirmed that ergotamine alkaloids and their derivatives (e.g., DHE) can negatively influence reproductive functions by direct or indirect reactions with spermatozoa that limit their motility [42]. Ergot alkaloids are not recommended for children due to the risk of cardiac valvular fibrosis [43].

DHE and other drug interactions. Due to possible interactions at the level of biotransformation, caution should be exercised when using other drugs that have an influence on liver enzymes. Due to the considerable participation of CYP3A4 in DHE metabolism, it is also necessary to exercise caution when using other medications metabolized by the same enzyme. Serious adverse reactions have been noted, such as vasospasm, cerebral ischemia, and/or ischemia of the extremities, when ergot alkaloids are used together with potential CYP3A4 inhibitors, such as protease inhibitors (e.g., delavirdine, indinavir, ritonavir, nelfinavir), antifungal drugs (e.g., ketoconazole, itraconazole), and macrolide antibiotics (e.g., clarithromycin, roxithromycin, erythromycin, troleandomycin) [23]. Such a combination of drugs decreases the effectiveness of the processes involving this enzyme, disturbs ergotamine metabolism, and can strengthen the drug's toxicity. It can also lead to serious or even lifethreatening peripheral ischemia. Furthermore, when DHE is used together with dopamine or dobutamine, the risk of peripheral ischemia increases, as well as the risk of tissue hypoxia, which can lead to necrosis of the fingers and toes. An interval of interval of at least 24 hours is recommended between DHE administration and the administration of other ergot alkaloids (e.g., ergotamine, methysergide) and sumatriptan [44]. During treatment with bromocriptine, cabergoline, $\alpha$-adrenolytics (tolazoline, prazosin), and $\beta$-adrenolytics (i.e., atenolol, nadolol, oxprenolol, propranolol, timolol), the use of DHE is contraindicated due to the possibility of hypertension, angina disease, and myocardial infraction. When used together with fluoxetine, fluvoxamine, paroxetine, or sertraline, serotonin syndrome symptoms can occur, such as general weakness, movement disorders, rigidity, and hyperthermia.

Possible adverse drug reactions. The data gathered thus far indicate that DHE preparations cause fewer adverse effects 
Table 6. Evaluation of combination therapy in patients with migraine

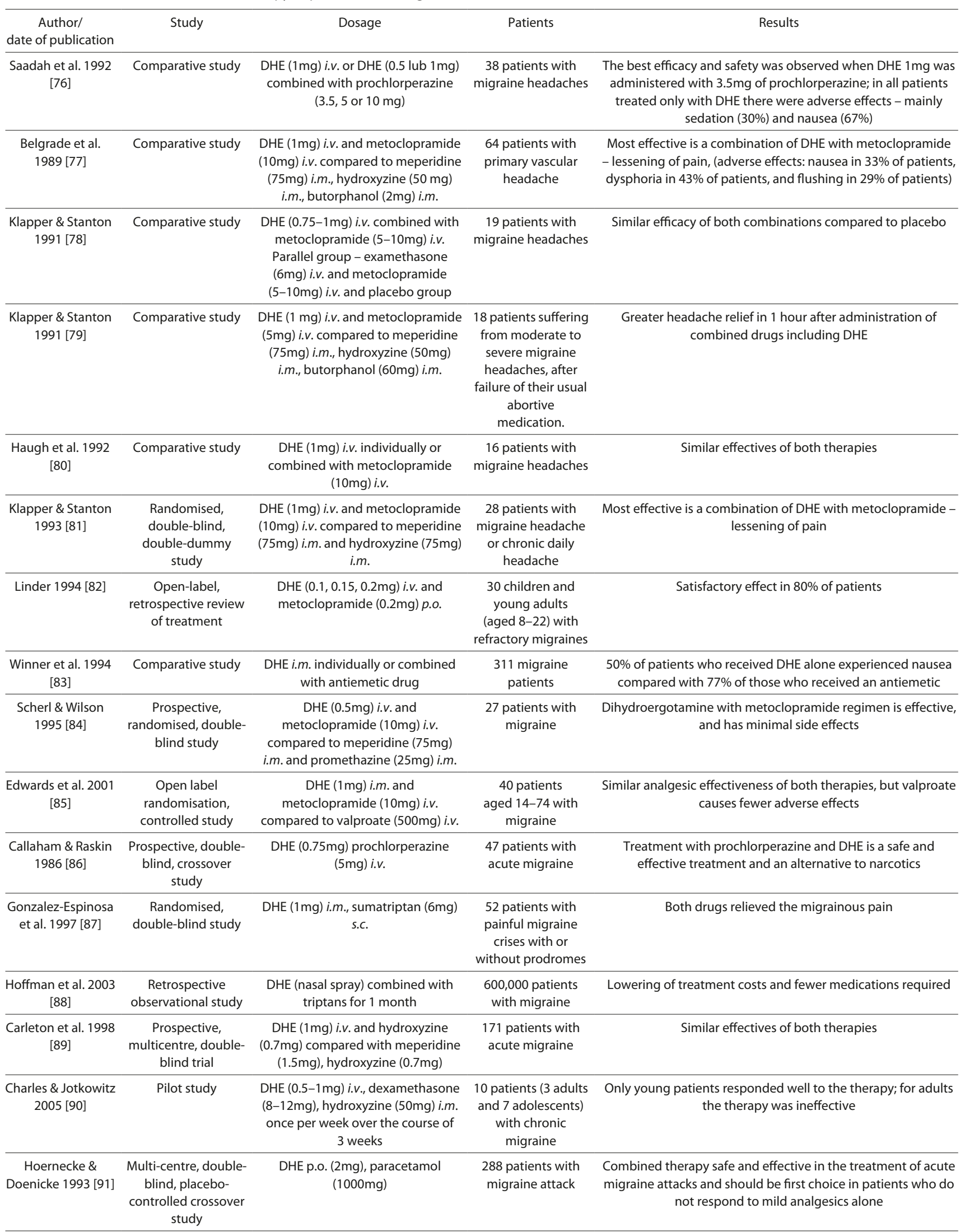


than the parent compound ergotamine. DHE is often given to patients together with antiemetic medication, such as metoclopramide or hydroxyzine, to relieve nausea and vomiting, as they are the most frequent adverse effects of DHE. The other most frequently reported adverse effects experienced by $1-70 \%$ of patients are diarrhea (2-30\%), constipation, abdominal pain, dryness in the mouth, and muscle pain and weakness (5-20\%) [23]. Other adverse reactions include abnormal speech, coma, drowsiness, confusion, convulsions (in the case of long-term use of large doses), hallucinations, numbness, tingling, and slowed breathing. Other side-effects that can occur include reversible vasospasm and peripheral ischemia symptoms (paraesthesia, pallor or cyanosis of the fingers and toes, feeling of coldness), especially if DHE is used in combination with heparin [45].

A case has been described of a 4-year-old patient with bowel ischemia after DHE administration, and the case of a 34-year-old patient who suffered from Balint syndrome after DHE [46, 47]. After combined administration of DHE (nasal) and sumatriptan (per os), transient global amnesia occurred [44]. Paradoxically, $10-40 \%$ of patients treated with DHE experience headaches and dizziness after excessive or prolonged use. DHE can also cause medication-overuse headache $(\mathrm{MOH})$; therefore, the use of this drug should be limited in the case of migraines to twice a week or 9 days in a month [48]. Long-term use of the drug may also produce symptoms that indicate liver or kidney damage.

Randomized, crossover, double-blind studies with placebo have not shown the influence of orally inhaled DHE (MAP004) at a dose lower than the therapeutic dose (3 mg) on the QT interval in healthy volunteers. After using the drug, patients may experience decreased or increased arterial blood pressure, tachycardia or bradycardia, coronary vasospasm, and myocardial ischemia or infarction [49]. Complications that rarely occur during short-term treatment include cutaneous lesions, such as erythema, petechiae, swelling, epidermal necrolysis, and acne.

Characteristic symptoms of DHE overdose are aggravated adverse effects affecting the central nervous system (e.g., convulsions, delirium, disturbance of consciousness, coma), cardiovascular system (e.g., peripheral vasospasm, cyanosis of extremities, decreased/imperceptible peripheral pulse, increased or decreased arterial blood pressure), and the digestive system. As there is no antidote, overdose symptoms can be subject only to symptomatic treatment. A considerable risk of ergotamine poisoning also exists, which can be lethal [40].

Another considerable problem with long-term use is the risk of tissue fibrosis as a result of serotonin receptor activation, including retroperitoneal fibrosis, pulmonary and pleural fibrosis, and heart valve fibrosis. Fibrotic changes occur in patients who use the drug over a long period of time. Some individual cases of renal artery spasm, peripheral ischemia, intermittent claudication, Raynaud's phenomenon, and gangrene have also been reported. Additionally, ergotamine derivatives can lead to addiction [50].

\section{CURRENT RECOMMENDATIONS FOR THE USE OF}

DHE. In 2013, the CHMP of the European Medicines Agency recommended restricting the use of ergotamine derivatives, declaring that treating diseases connected with circulatory disorders, orthostatic hypotonia, cognitive disorders, and sensory disorders (with the exception of Alzheimer's disease and other types of dementia), as well as using ergotamine derivatives in migraine prevention, is unjustified because the risk of serious adverse events (poisoning, tissues fibrosis) outweighs the potential benefits of such therapy [40]. Reviews regarding clinical studies describing the way the drug works, its efficacy and safety, show that it is also possible to use DHE preparations in modern migraine therapy. Although the efficacy of DHE is comparable to sumatriptans according to some authors, in acute migraine therapy the recommended medications include non-steroidal anti-inflammatory drugs and triptans $[43,51,52]$. Opinions on the antimigraine efficacy of DHE are incnsistant, but DHE in combination with antiemetic drugs seems to be as effective as using opiates, ketorolac, or valproate, and this combination can be applied successfully in some slinical cases [40]. According to new clinical recommendation (evidence rating B) parenteral DHE should be reserved for the treatment of status migrainosus and refractory migraine [38]. The availability of new formulations and adminstration of DHE with breath-synchronized inhaler creates wider and more safe possibilities for therapeutic use of the drug [3].

A retrospective analysis of 11 clinical studies comparing the efficacy and economic aspects of migraine therapy using subcutaneous DHE and sumatriptans did not lead to consistent conclusions. In 3 of the studies, similar efficacy was recorded for both drugs, which led to the application of the less costly DHE therapy. Four studies showed that DHE is more effective and results in lower treatment costs. However, in the remaining 4 studies, sumatriptans were found to be better in terms of both efficacy and incremental cost-efficacy ratios [53]. There is a need for a more individualized therapy based on the pattern and severity of migraine attack. This indicates a need for further analysis and additional evaluation.

The standpoint on using DHE in migraine headaches should be reviewed because of the availability of new formulations that can be characterized by fewer adverse effects. DHE may be an alternative to other widely recommended drugs in the acute treatment of refractory migraine and cluster headache episodes.

\section{REFERENCES}

1. Morren JA, Galvez-Jimenez N. Where is dihydroergotamine mesylate in the changing landscape of migraine therapy? Expert Opin Pharmacother. 2010; 11(18): 3085-93.

2.Becker WJ. Cluster headache: conventional pharmacological management. Headache. 2013; 53(7): 1191-6.

3. Marmura MJ, Silberstein SD, Schwedt TJ. The acute treatment of migraine in adults: the american headache society evidence assessment of migraine pharmacotherapies. Headache. 2015; 55(1): 3-20.

4. Müller-Schweinitzer E. Alpha-adrenoceptors, 5-hydroxytryptamine receptors and the action of dihydroergotamine in human venous preparations obtained during saphenectomy procedures for varicose veins. Naunyn Schmiedebergs Arch Pharmacol. 1984; 327(4): 299-303.

5. Lesage AS, Wouters R, Van Gompel P, Heylen L, Vanhoenacker P, Haegeman G, Luyten WH, Leysen JE. Agonistic properties of alniditan, sumatriptan and dihydroergotamine on human 5-HT1B and 5-HT1D receptors expressed in various mammalian cell lines. Br J Pharmacol. 1998; 123(8): 1655-65.

6. Hanoun N, Saurini F, Lanfumey L, Hamon M, Bourgoin S. Dihydroergotamine and its metabolite, 8'-hydroxy-dihydroergotamine, as 5-HT1A receptor agonists in the rat brain. Br J Pharmacol. 2003; 139(2): 424-34.

7. Schaerlinger B, Hickel P, Etienne N, Guesnier L, Maroteaux L. Agonist actions of dihydroergotamine at 5-HT2B and 5-HT2C receptors and their possible relevance to antimigraine efficacy. Br J Pharmacol. 2003; 140(2): 277-84. 
8. Dahlöf C, Maassen Van Den Brink A. Dihydroergotamine, ergotamine, methysergide and sumatriptan - basic science in relation to migraine treatment. Headache. 2012; 52(4): 707-14.

9. Masterson CG, Durham PL. DHE repression of ATP-mediated sensitization of trigeminal ganglion neurons. Headache. 2010; 50(9): 1424-39.

10. Silberstein SD, McCrory DC. Ergotamine and dihydroergotamine: history, pharmacology, and efficacy. Headache. 2003; 43(2): 144-66.

11. Kelley NE, Tepper DE. Rescue therapy for acute migraine, part 1: triptans, dihydroergotamine, and magnesium. Headache. 2012; 52(1): 114-28.

12. Suzuki K, Aimi T, Ishihara T, Mizushima T. Identification of approved drugs that inhibit the binding of amyloid $\beta$ oligomers to ephrin type- $\mathrm{B}$ receptor 2. FEBS Open Bio. 2016; 6(5): 461-8.

13. Silberstein SD, Kori SH. Dihydroergotamine: a review of formulation approaches for the acute treatment of migraine.CNS Drugs. 2013; 27(5): 385-94.

14. Little PJ, Jennings GL, Skews H, Bobik A. Bioavailability of dihydroergotamine in man. Br J Clin Pharmacol. 1982; 13(6): 785-90.

15. Barthel W. [Venous tonus-modifying effect, pharmacokinetics and undesired effects of dihydroergotamine]. Z Gesamte Inn Med. 1984; 39(17): 417-28.

16. van der Kuy PH, Lohman JJ, Hooymans PM, Ter Berg JW, Merkus FW. Bioavailability of intranasal formulations of dihydroergotamine. Eur J Clin Pharmacol. 1999; 55(9): 677-80.

17. Saper JR, Silberstein S. Pharmacology of dihydroergotamine and evidence for efficacy and safety in migraine. Headache. 2006; 46 Suppl 4: S171-81.

18. Shrewsbury SB, Kori SH, Miller SD, Pedinoff A, Weinstein S. Randomized, double-blind, placebo-controlled study of the safety, tolerability and pharmacokinetics of MAP0004 (orally-inhaled DHE) in adult asthmatics. Curr Med Res Opin. 2008; 24(7): 1977-85.

19. Cook RO, Shrewsbury SB, Ramadan NM. Reduced adverse event profile of orally inhaled DHE (MAP0004) vs IV DHE: potential mechanism. Headache. 2009; 49(10): 1423-34.

20. Silberstein S. MAP0004: dihydroergotamine mesylate inhalation aerosol for acute treatment of migraine. Expert Opin Pharmacother. 2012; 13(13): 1961-8.

21. Wyss PA, Rosenthaler J, Nüesch E, Aellig WH. Pharmacokinetic investigation of oral and i.v. dihydroergotamine in healthy subjects. Eur J Clin Pharmacol. 1991; 41(6): 597-602.

22. Aellig WH. Investigation of the venoconstrictor effect of 8 hydroxydihydroergotamine, the main metabolite of dihydroergotamine, in man. Eur J Clin Pharmacol. 1984; 26(2): 239-42.

23. Buck M. Intravenous Dihydroergotamine (DHE) for the Treatment of Refractory Migraines. Pediatric Pharmacotherapy. 2007; 13(7): 1-4.

24. Pradalier A, Lantéri-Minet M, Géraud G, Allain H, Lucas C, Delgado A. The PROMISE study: PROphylaxis of MIgraine with SEglor (dihydroergotamine mesilate) in French primary care. CNS Drugs. 2004; 18(15): 1149-63

25. Hämäläinen ML, Hoppu K, Santavuori PR. Oral dihydroergotamine for therapy-resistant migraine attacks in children. Pediatr Neurol. 1997; 16(2): 114-7.

26. Patniyot IR, Gelfand AA. Acute Treatment Therapies for Pediatric Migraine: A Qualitative Systematic Review. Headache. 2016; 56(1): 49-70.

27. Ford RG, Ford KT. Continuous intravenous dihydroergotamine in the treatment of intractable headache. Headache. 1997; 37(3): 129-36.

28. Magnoux E, Zlotnik G. Outpatient intravenous dihydroergotamine for refractory cluster headache. Headache. 2004; 44(3): 249-55.

29. Kabbouche MA, Powers SW, Segers A, LeCates S, Manning P, Biederman S, Vaughan P, Burdine D, Hershey AD. Inpatient treatment of status migraine with dihydroergotamine in children and adolescents. Headache. 2009; 49(1): 106-9.

30. Charles JA, von Dohln P. Outpatient home-based continuous intravenous dihydroergotamine therapy for intractable migraine. Headache. 2010; 50(5): 852-60.

31. Becker WJ. Cluster headache: conventional pharmacological management. Headache. 2013; 53(7): 1191-6.

32. Tepper SJ. Orally inhaled dihydroergotamine: a review. Headache. 2013; 53 Suppl 2: 43-53.

33. Mathew PG, Krel R, Buddhdev B, Ansari H, Joshi SG, Spinner WD, Klein BC. A retrospective analysis of triptan and dhe use for basilar and hemiplegic migraine. Headache. 2016 Apr 8. doi: 10.1111/head.12804. [Epub ahead of print]

34. El-Chammas K, Keyes J, Thompson N, Vijayakumar J, Becher D, Jackson JL. Pharmacologic treatment of pediatric headaches: a meta-analysis. JAMA Pediatr. 2013; 167(3): 250-8.
35. Silver S, Gano D, Gerretsen P. Acute treatment of paediatric migraine: a meta-analysis of efficacy. J Paediatr Child Health. 2008; 44(1-2): 3-9.

36. Whyte CA, Stillman MJ, Tepper SJ. Dihydroergotamine and its use in migraine with posterior fossa symptoms. Headache. 2010; 50(9): 1419-23.

37. Tfelt-Hansen PC. Relatively slow and long-lasting antimigraine effect of dihydroergotamine is most likely due to basic pharmacological attributes of the drug: a review. Cephalalgia. 2013; 33(13): 1122-31.

38. Mayans L, Walling A. Acute Migraine Headache: Treatment Strategies. Am Fam Physician. 2018; 97(4): 243-251.

39. Colman I, Brown MD, Innes GD, Grafstein E, Roberts TE, Rowe BH. Parenteral dihydroergotamine for acute migraine headache: a systematic review of the literature. Ann Emerg Med. 2005; 45(4): 393-401.

40. EMA. Overall summary of the scientific evaluation of dihydroergotamine containing medicinal products (Annex I, II) http: //www.ema.europa. eu/docs/en_GB/document Library/Referrals_document/Ergot_ derivatives-containing_products.

41. Bérard A, Kori S. Dihydroergotamine (DHE) use during gestation and the risk of adverse pregnancy outcomes. Headache. 2012; 52(7): 1085-93.

42. Wang H, Looper ML, Johnson ZB, Rorie RW, Rosenkrans CF Jr. Involvement of signaling pathways in bovine sperm motility, and effect of ergot alkaloids. In Vitro Cell Dev Biol Anim. 2009; 45(8): 483-9.

43. Evers S, Afra J, Frese A, Goadsby PJ, Linde M, May A, Sándor PS; European Federation of Neurological Societies. EFNS guideline on the drug treatment of migraine--revised report of an EFNS task force. Eur J Neurol. 2009; 16(9): 968-81.

44. Pradalier A, Lutz G, Vincent D. Transient global amnesia, migraine, thalamic infarct, dihydroergotamine, and sumatriptan. Headache. 2000; 40(4): 324-7.

45. Bachner EJ1, Konsens RM, Priem L, King T, Froimson AI. Reversible vasospasm in association with the use of heparin and dihydroergotamine. Clin Orthop Relat Res. 1992; (283): 261-4.

46. Padon A, Ostadian M, Wright C, Pohl J, Crisp D, Easley D. Dihydroergotamine-associated intestinal ischemia in a child with cyclic vomiting syndrome. J Pediatr Gastroenterol Nutr. 2006; 42(5): 573-5.

47. Kelley BJ, Samples S, Kunkel R. PRES following administration of DHE in a patient with unsuspected pheochromocytoma. Headache. 2008; 48(8): 1237-9.

48. Tfelt-Hansen PC, Diener HC. Use of dihydroergotamine (DHE) should be restricted to no more than twice a week. Headache. 2014; 54(9): 1523-5.

49. Kori S, Kellerman DJ, Voloshko P, Haugen G. Effects of a supratherapeutic dose of investigational orally inhaled dihydroergotamine (MAP0004) on QT interval: a randomized, double-blind, active- and placebocontrolled crossover study in healthy volunteers. Clin Ther. 2012; 34(9): 1920-8

50. Beau-Salinas F, Jonville-Béra AP, Cissoko H, Bensouda-Grimaldi L, Autret-Leca E. Drug dependence associated with triptans and ergot derivatives: a case/non-case study. Eur J Clin Pharmacol. 2010; 66(4): 413-7.

51. Kozma CM, Reeder CE. Comparison of the economic, clinical, and humanistic attributes of dihydroergotamine and sumatriptan. Clin Ther. 1995; 17(2): 315-9.

52. Orr SL, Aubé M, Becker WJ, Davenport WJ, Dilli E, Dodick D, Giammarco R, Gladstone J, Leroux E, Pim H, Dickinson G, Christie SN. Canadian Headache Society systematic review and recommendations on the treatment of migraine pain in emergency settings. Cephalalgia. 2015; 35(3): 271-84.

53. Payne K, Kozma CM, Lawrence BJ. Comparing dihydroergotamine mesylate and sumatriptan in the management of acute migraine. A retrospective cost-efficacy analysis. Pharmacoeconomics. 1996; 10(1): $59-71$.

54. Bell R, Montoya D, Shuaib A, Lee MA. A comparative trial of three agents in the treatment of acute migraine headache. Ann Emerg Med. 1990; 19(10): 1079-82.

55. Queiroz LP, Weeks RE, Rapoport AM, Sheftell FD, Baskin SM, Siegel SE. Early and transient side effects of repetitive intravenous dihydroergotamine. Headache. 1996; 36(5): 291-4.

56. Nagy AJ, Gandhi S, Bhola R, Goadsby PJ. Intravenous dihydroergotamine for inpatient management of refractory primary headaches. Neurology. 2011; 77(20): 1827-32.

57. Raina M, Chelimsky G, Chelimsky T. Intravenous dihydroergotamine therapy for pediatric abdominal migraines. Clin Pediatr (Phila). 2013; 52(10): $918-21$

58. Lambru G, Shanahan P, Matharu M. Exacerbation of SUNCT and SUNA syndromes during intravenous dihydroergotamine treatment: A case series. Cephalalgia. 2015; 35(12): 1115-24. 
59. Eller M, Gelfand AA, Riggins NY, Shiboski S, Schankin C, Goadsby PJ. Exacerbation of headache during dihydroergotamine for chronic migraine does not alter outcome. Neurology. 2016; 86(9): 856-9.

60. Nelson GR, Bale JF, Kerr LM. Outcome and Cost of Inpatient Hospitalization for Intravenous Dihydroergotamine Treatment of Refractory Pediatric Headache. Pediatr Neurol. 2017; 66: 76-81.

61. Aurora SK, Rozen TD, Kori SH, Shrewsbury SB. A randomized, double blind, placebo-controlled study of MAP0004 in adult patients with migraine. Headache. 2009; 49(6): 826-37.

62. Aurora SK, Silberstein SD, Kori SH, Tepper SJ, Borland SW, Wang M, Dodick DW. MAP0004, orally inhaled DHE: a randomized, controlled study in the acute treatment of migraine. Headache. 2011; 51(4): 507-17.

63. Tepper SJ, Kori SH, Borland SW, Wang MH, Hu B, Mathew NT, Silberstein SD. Efficacy and safety of MAP0004, orally inhaled DHE in treating migraines with and without allodynia. Headache. 2012; 52(1): 37-47.

64. Winner P, Ricalde O, Le Force B, Saper J, Margul B. A double-blind study of subcutaneous dihydroergotamine vs subcutaneous sumatriptan in the treatment of acute migraine. Arch Neurol. 1996; 53(2): 180-4.

65. Saadah HA. Abortive headache therapy with intramuscular dihydroergotamine. Headache. 1992; 32(1): 18-20.

66. Silberstein SD, Young WB, Hopkins MM, Gebeline-Myers C, Bradley KC. Dihydroergotamine for early and late treatment of migraine with cutaneous allodynia: an open-label pilot trial. Headache. 2007; 47(6): 878-85.

67. Andersson PG, Jespersen LT. Dihydroergotamine nasal spray in the treatment of attacks of cluster headache. A double-blind trial versus placebo. Cephalalgia. 1986; 6(1): 51-4.

68. Tulunay FC, Karan O, Aydin N, Culcuoglu A, Guvener A. Dihydroergotamine nasal spray during migraine attacks. A doubleblind crossover study with placebo. Cephalalgia. 1987; 7(2): 131-3.

69. Jenzer G, Bremgartner MF. [Dihydroergotamine as a nasal spray in the therapy of migraine attacks. Efficacy and tolerance]. Schweiz Rundsch Med Prax. 1990; 79(31-32): 914-7.

70.Ziegler D, Ford R, Kriegler J, Gallagher RM, Peroutka S, Hammerstad J, Saper J, Hoffert M, Vogel B, Holtz N, et al. Dihydroergotamine nasal spray for the acute treatment of migraine. Neurology. 1994; 44(3 Pt 1): 447-53

71. Touchon J, Bertin L, Pilgrim AJ, Ashford E, Bès A. A comparison of subcutaneous sumatriptan and dihydroergotamine nasal spray in the acute treatment of migraine. Neurology. 1996; 47(2): 361-5.

72. Treves TA, Kuritzky A, Hering R, Korczyn AD. Dihydroergotamine nasal spray in the treatment of acute migraine. Headache. $1998 ; 38(8)$ : 614-7.

73. Boureau F, Kappos L, Schoenen J, Esperanca P, Ashford E. A clinical comparison of sumatriptan nasal spray and dihydroergotamine nasa spray in the acute treatment of migraine. Int J Clin Pract. 2000; 54(5): 281-6.

74. Weintraub J. Repetitive dihydroergotamine nasal spray for treatment of refractory headaches: an open-label pilot study. Curr Med Res Opin. 2006; 22(10): 2031-6.

75. Fisher M, Gosy EJ, Heary B, Shaw D. Dihydroergotamine nasal spray for relief of refractory headache: a retrospective chart review. Curr Med Res Opin. 2007; 23(4): 751-5.
76. Saadah HA. Abortive headache therapy in the office with intravenous dihydroergotamine plus prochlorperazine. Headache. 1992; 32(3): $143-6$.

77. Belgrade MJ, Ling LJ, Schleevogt MB, Ettinger MG, Ruiz E. Comparison of single-dose meperidine, butorphanol, and dihydroergotamine in the treatment of vascular headache. Neurology. 1989; 39(4): 590-2.

78. Klapper JA, Stanton JS. Ketorolac versus DHE and metoclopramide in the treatment of migraine headaches. Headache. 1991; 31(8): 523-4.

79. Klapper JA, Stanton JS. The emergency treatment of acute migraine headache: a comparison of intravenous dihydroergotamine, dexamethasone, and placebo. Cephalalgia. 1991; 11: 159-160.

80. Haugh MJ, Lavender L, Jensen A, Giuliano R. An office-based doubleblind comparison of dihydroergotamine vs dihydroergotamine/ metoclopramide in the treatment of acute migraine. Headache. 1992; 32: 251.

81. Klapper JA, Stanton J. Current emergency treatment of severe migraine headaches. Headache. 1993; 33(10): 560-2.

82. Linder SL.Treatment of childhood headache with dihydroergotamine mesylate. Headache. 1994; 34(10): 578-80.

83. Winner P, Dalessio D, Mathew N, Sadowsky C, Turkewitz LJ, Sheftell F, Silberstein SD, Solomon S. Concomitant administration of antiemetics is not necessary with intramuscular dihydroergotamine. Am J Emerg Med. 1994; 12(2): 138-41.

84. Scherl ER, Wilson JF. Comparison of dihydroergotamine with metoclopramide versus meperidine with promethazine in the treatment of acute migraine. Headache. 1995; 35(5): 256-9.

85. Edwards KR, Norton J, Behnke M. Comparison of intravenous valproate versus intramuscular dihydroergotamine and metoclopramide for acute treatment of migraine headache. Headache. 2001; 41(10): 976-80.

86. Callaham M, Raskin N. A controlled study of dihydroergotamine in the treatment of acute migraine headache. Headache. 1986; 26(4): 168-71.

87. González-Espinosa LE, Gómez-Viera N, Olivera-Leal I, Reyes-Lorente R. [Treatment of acute attack of migraine with sumatriptan]. Rev Neurol. 1997; 25(147): 1672-5.

88.Hoffman L, Mayzell G, Pedan A, Farrell M, Gilbert T. Evaluation of a monthly coverage maximum (drug-specific quantity limit) on the 5-HT1 agonists (triptans) and dihydroergotamine nasal spray. J Manag Care Pharm. 2003; 9(4): 335-45.

89. Carleton SC, Shesser RF, Pietrzak MP, Chudnofsky CR, Starkman S, Morris DL, Johnson G, Rhee KJ, Barton CW, Chelly JE, Rosenberg J, Van Valen MK. Double-blind, multicenter trial to compare the efficacy of intramuscular dihydroergotamine plus hydroxyzine versus intramuscular meperidine plus hydroxyzine for the emergency department treatment of acute migraine headache. Ann Emerg Med. 1998; 32(2): 129-38.

90. Charles JA, Jotkowitz S. Observations of the "carry-over effect" following successful termination of chronic migraine in the adolescent with shortterm dihydroergotamine, dexamethasone and hydroxyzine: a pilot study. J Headache Pain. 2005; 6(1): 51-4.

91. Hoernecke R, Doenicke A. [Treatment of migraine attacks: combination of dihydroergotamine tartrate and paracetamol in comparison with individual drugs and placebo]. Med Klin (Munich). 1993; 88(11): 642-8. 